\title{
Does the Crowd-Out Effect of R\&D Subsidies Exist in the Pharmaceutical Industry? Evidence from Chinese Companies
}

\author{
Kejin Ni \\ College of Economics, Jinan University, Guangzhou, China \\ Email: nikejin_edu@163.com
}

How to cite this paper: Ni, K. J. (2020). Does the Crowd-Out Effect of R\&D Subsidies Exist in the Pharmaceutical Industry? Evidence from Chinese Companies. Modern Economy, 11, 645-656. https://doi.org/10.4236/me.2020.113048

Received: February 7, 2020

Accepted: March 10, 2020

Published: March 13, 2020

Copyright $\odot 2020$ by author(s) and Scientific Research Publishing Inc. This work is licensed under the Creative Commons Attribution International License (CC BY 4.0).

http://creativecommons.org/licenses/by/4.0/

\section{(c) (i) Open Access}

\begin{abstract}
Dissenting from existing multi-industries work, this paper particularly takes the pharmaceutical entities in the Chinese industrial enterprise database as a sample and uses the threshold regression to examine the impact of government $R \& D$ subsidies on private $R \& D$ investment, patent quantity and new product sales. We find that government $R \& D$ subsidies can effectively crowd in private investment. However, due to the crowd-out threshold is too high, the crowd-out effect does not actually exist in the pharmaceutical industry. A similar story happens to new product sales; but for the number of patents, there is only promoting effect.
\end{abstract}

Keywords

R\&D Subsidies, Crowd-Out Effect, Pharmaceutical Industry, Threshold Regression

\section{Introduction}

With the advancement of modern biotechnology, the pharmaceutical industry is getting more and more achievements. Its growth rate has reached a new peak in recent years. During the "Twelfth Five-Year Plan" period, the annual growth rate of China's pharmaceutical industry reached $33.61 \%$. However, the current R\&D capabilities pharmaceutical companies in China are far behind the market needs and international advanced levels. Most of the products are generic drugs. Especially, the R\&D investment of Chinese companies is insufficient. Take several major multinational pharmaceutical companies as examples. In 2016, Pfizer's R\&D investment intensity (R\&D funding input/main business income) was $17.8 \%$, Novartis's R\&D investment intensity was $19.9 \%$, and Roche's R\&D in- 
vestment intensity was $21.8 \%$. And Astra Zeneca Pharmaceuticals is as high as $24.1 \%$. Respect to the figure, the annual $R \& D$ investment intensity of major pharmaceutical companies generally exceeds $15 \%$ of their income, and the amount is as high as 500 million to 1 billion dollars. However, the average R\&D investment intensity of Chinese pharmaceutical companies is less than 3\% (Zhao \& Sun, 2003).

As China's GDP growth rate continues to decline, its economic development pattern needs to shift from the previous factor-driven to an innovation-driven. For various industries, how to enhance innovation strength has become their focus. The disadvantages of Chinese pharmaceutical companies in R\&D investment and innovation capabilities have a lot to do with the characteristics of the pharmaceutical industry itself. Drug development is a long-circle, high-risk and high-input project. Even for international pharmaceutical giants, it also takes an average of ten years to develop a new drug and the risk of failure is high. Therefore, in order to avoid risks, many Chinese pharmaceutical companies are less willing to invest in $\mathrm{R} \& \mathrm{D}$ and prefer to purchase patents and produce generic drugs.

Many existing studies have divergent views on the "crowding in" and "crowding out" effects of R\&D subsidies (Gorg \& Strobl, 2007; Lach, 2002). The reason may be that the heterogeneity of $R \& D$ activities in different industries is not fully considered, that is, R\&D activities across industries vary a lot in research and development duration, risk levels and capital consumption (Wallsten, 2000). Therefore, pharmaceutical companies heterogeneously respond to government subsidies.

The R\&D subsidies can have a significant boost for companies in some industries while crowding out private investment in other industries. For those R\&D activities with large capital needs, R\&D subsidies may only have a "crowding in" effect. Most of the existing researches have examined the R\&D activities of all industries together, which may lead to inconsistent results.

A paper that caught our attention was the research by Tor Jakob Klette, and Jarle Moen (Klette \& Moen, 2011). They focused their research on Norwegian high-tech industries, which have high-risk R\&D activities and high capital investment. They found that government $\mathrm{R} \& \mathrm{D}$ subsidies did not crowd out private investment. Therefore, we believe that considering the differences in R\&D activities across industries will help open new directions for R\&D subsidy research.

This article takes the pharmaceutical manufacturing companies in the database of China's industrial companies as a sample and uses the threshold regression method to investigate the impact of government $\mathrm{R} \& \mathrm{D}$ subsidies on pharmaceutical companies' private $\mathrm{R} \& \mathrm{D}$ investment, the number of patents, and new product sales. Our research finds that government R\&D subsidies can effectively promote private investment in pharmaceutical companies, but the effect of crowding out private investment does not exist because the threshold for "crowding out" is too high; the same story happened on new products, and it only has a promoting effect on the number of patents.

This paper has two contributions. First, we give the evidence that for pharma- 
ceutical R\&D activities, the crowding-out effect of government R\&D subsidies does not exist in practice. Second, we highlight that differences in R\&D activities across industries should be included in R\&D subsidy research.

The remainder of this paper is organized as follows: Section 2 introduces our data; Section 3 explains the model; Section 4 shows our benchmark results, robustness test, and endogenous discussion; and Section 5 concludes.

\section{Data}

Our sample is from the 2010 China Industrial Companies Database. This database was established by the National Bureau of Statistics in China, and the data mainly comes from the quarterly and annual report summary submitted by the sample enterprises to the local statistical bureau. Its sample scope covers all state-owned industrial enterprises and non-state-owned industrial enterprises above designated size, and its statistical unit is corporate (Chen, 2018). In 2010, the database investigated more than 460,000 companies, of which 7802 are pharmaceutical companies. The dataset includes the company's research and development costs, annual revenue, total employees, year of establishment, and shareholding structure. Statistical summary of our data is shown in Table 1.

The patent data comes from the China National Patent Office, and then we match the companies in the patent database with the companies in the China Industrial Companies Database by company name. Other information about the company, such as research and development subsidies, sales of new products, number of researchers, etc., we extract from the annual report of the company, company announcements, and other documents. In the end, we obtained a sample of 6715 companies, accounting for $86 \%$ of the total pharmaceutical companies surveyed.

\section{Model}

This article attempts to estimate the effect of government subsidies on pharmaceutical companies' R\&D activities at different threshold levels. We can use the

Table 1. Statistical summary.

\begin{tabular}{cccccc}
\hline Variables & N & Mean & Sd & Min & Max \\
\hline Private R\&D investment & 6715 & $103,000,000$ & 5785 & 0 & $2,000,000,000$ \\
Number of patents & 6715 & 3.959 & 9.07 & 0 & 63 \\
Sales of new products & 6715 & $392,910,000$ & 12,299 & 0 & $38,630,000,000$ \\
Total income & 6715 & $1,052,410,000$ & 372,141 & $-360,392$ & $131,000,000,000$ \\
R\&D subsidy & 6715 & $4,272,000$ & 3212 & 0 & $1,286,100,000$ \\
Researcher & 6715 & 42.9 & 97.62 & 0 & 1580 \\
Total number of employ & 6715 & 235.7 & 564.4 & 245 & 19,949 \\
Firm's age & 6715 & 17.24 & 14.31 & 7 & 414 \\
Shareholding structure & 6715 & 0.163 & 0.37 & 0 & 1 \\
\hline
\end{tabular}


threshold regression method proposed by Hansen (1999) to achieve the dynamic analysis expected in this research. First, we set the benchmark model as follows.

$$
Y_{i}=\alpha+\beta_{1} S_{i}+\beta_{2} X_{i}^{\prime}+\eta_{i}+\varepsilon
$$

$Y_{i}$ denotes a set of output variables of the company (private R\&D expenditure, sales of new products/total operating income, number of patents). $S_{i}$ indicates that pharmaceutical companies have received government $R \& D$ subsidies, and we use the annual deduction method of net fixed asset weights, that is, the total government $\mathrm{R} \& \mathrm{D}$ subsidies are allocated to each year of the project's validity period according to the weight of the company's net fixed assets. We calculate the amount of R\&D subsidies received by companies in each year ( $\mathrm{Li} \&$ $\mathrm{Ba}, 2013) . \quad X_{i}^{\prime}$ is a set of control variables, including the number of $\mathrm{R} \& \mathrm{D}$ personnel, the size of the enterprise, the number of years of the enterprise, and the proportion of share state-owned ( $\mathrm{Zhu} \& \mathrm{Xu}, 2003) . \quad \eta_{i}$ represents an individual fixed effect, and $\varepsilon$ represents a random error term.

In recent years, the development of non-linear econometric models has provided good technical methods for further exploration of economic issues. Threshold regression, as an extension of the group test method, provides a new direction for refining the effects of research and development subsidies. The main idea of the threshold model proposed by Hansen (1999) is:

$$
\begin{aligned}
& y_{n}=\beta_{1} x_{n}+e_{n}, q_{n} \leq \gamma \\
& y_{n}=\beta_{2} x_{n}+e_{n}, q_{n}>\gamma
\end{aligned}
$$

$y_{n}$ is the dependent variable and $x_{n}$ is the independent variable. $\gamma$ is a threshold variable, and its role is to divide the sample into different groups $q_{n}$, We define the indicator variable $T_{n}(\gamma)=\left(q_{n} \leq \gamma\right)$, that is, when $q_{n} \leq \gamma, T_{n}(\gamma)=1$, otherwise $T_{n}(\gamma)=0$.

$$
y_{n}=\beta x_{n}+\theta x_{n} T_{n}(\gamma)+e_{n}, e \sim\left(0, \delta_{n}^{2}\right)
$$

For any threshold $\gamma$, the estimated values of each parameter can be obtained by summing the squared residuals $\operatorname{Se}(\gamma)=e_{i}(\gamma)^{\prime} e_{i}(\gamma)$. The optimal threshold $\hat{\gamma}$ should minimize the squared sum of $\operatorname{Se}(\gamma)$ residuals.

Similarly, we follow the previous steps to build a threshold model suitable for this study. Our threshold model can be set as:

$$
Y_{i}=\alpha+\beta_{1} S_{i} T_{n}(\gamma)+\beta_{2} X_{i}^{\prime}+\eta_{i}+\varepsilon
$$

The specific form of the single threshold model is

$$
Y_{i}=\alpha+\beta_{1} S_{i} T_{1}\left(s_{i} \leq \gamma\right)+\beta_{2} S_{i} T_{2}\left(s_{i}>\gamma\right)+\beta_{3} X_{i}^{\prime}+\eta_{i}+\varepsilon
$$

The specific form of the double threshold model is:

$$
\begin{aligned}
Y_{i}= & \alpha+\beta_{1} S_{i} T_{1}\left(s_{i} \leq \gamma_{1}\right)+\beta_{2} S_{i} T_{2}\left(\gamma_{1}<s_{i} \leq \gamma_{2}\right) \\
& +\beta_{3} S_{i} T_{3}\left(s_{i}>\gamma_{3}\right)+\beta_{4} X_{i}^{\prime}+\eta_{i}+\varepsilon
\end{aligned}
$$

and so forth. 


\section{Results}

\subsection{Threshold Quantity and the Threshold Value}

In threshold regression, in order to determine the specific form of the model, the number of thresholds needs to be determined first. Here we test the applicability of single threshold, double thresholds, and triple thresholds. It can be seen from Table 2 that the model passed the single threshold test and the double threshold test but failed to pass the triple threshold test, indicating that our model should be set to a dual-threshold regression model.

Next, we calculated the thresholds for R\&D subsidies and 95\% confidence intervals for the three explanatory variables, and they are shown in Table 3.

\subsection{Benchmark Results}

Table 4 shows our benchmark results. First, in columns 1 to 3 , we used OLS to perform regression and found that $\mathrm{R} \& \mathrm{D}$ subsidies have a positive effect on private $R \& D$ investment, new product sales, and the number of patents. This is consistent with the results of existing research. The adjusted model $R^{2}$ is about 0.06 . In columns 4 to 6 , we used a double threshold regression model. The adjusted $R^{2}$ of the model rose to about 0.11 , which also reflects that the threshold regression model is suitable in this study.

The fourth column of Table 4 reports the impact of R\&D subsidies on private $\mathrm{R} \& \mathrm{D}$ investment at different thresholds. When the proportion of government $R \& D$ subsidies in the total $R \& D$ expenditure of an enterprise is less than $1.1 \%$, the government $\mathrm{R} \& \mathrm{D}$ subsidy will also have a positive impact on the private

Table 2. Threshold number test.

\begin{tabular}{cccc}
\hline Test type & Private R\&D investment & New product sales & Number of patents \\
\hline Single threshold test & $17.251^{\star * \star}$ & $9.262^{\star *}$ & $7.732^{\star *}$ \\
Double threshold test & $(0.000)$ & $(0.013)$ & $(0.043)$ \\
& $15.471^{\star * *}$ & $20.861^{\star * *}$ & $19.562^{\star * *}$ \\
Triple threshold test & $(0.000)$ & $(0.003)$ & $(0.001)$ \\
Bootstrap times & 4.821 & 3.151 & 1.791 \\
& $(0.897)$ & $(0.578)$ & $(0.734)$ \\
\hline
\end{tabular}

Note: ${ }^{* *},{ }^{* *},{ }^{*}$ represent $1 \%, 5 \%$, and $10 \%$ level of significance.

Table 3. Threshold value estimation results.

\begin{tabular}{cccc}
\hline Threshold type & Private R\&D investment & New product sales & Number of patents \\
\hline First threshold & 0.011 & 0.065 & 0.027 \\
Second threshold & {$[0.0094,0.0116]$} & {$[0.0617,0.0682]$} & {$[0.0427,0.0472]$} \\
& 1.782 & 0.819 & 1.982 \\
\hline
\end{tabular}


Table 4. Benchmark results.

\begin{tabular}{|c|c|c|c|c|c|c|}
\hline & 1 & 2 & 3 & 4 & 5 & 6 \\
\hline Variables & $\begin{array}{c}\text { Ln (Private } \\
\text { R\&D } \\
\text { investment) }\end{array}$ & $\begin{array}{l}\mathrm{Ln}(\mathrm{New} \\
\text { product } \\
\text { sales })\end{array}$ & $\begin{array}{l}\text { Ln (Number } \\
\text { of patents) }\end{array}$ & $\begin{array}{c}\text { Ln (Private } \\
\mathrm{R} \& \mathrm{D} \\
\text { investment) }\end{array}$ & $\begin{array}{l}\text { Ln (New } \\
\text { product } \\
\text { sales) }\end{array}$ & $\begin{array}{c}\text { Ln (Number } \\
\text { of patents) }\end{array}$ \\
\hline Methods & OLS & OLS & OLS & $\begin{array}{l}\text { Threshold } \\
\text { regression }\end{array}$ & $\begin{array}{l}\text { Threshold } \\
\text { regression }\end{array}$ & $\begin{array}{l}\text { Threshold } \\
\text { regression }\end{array}$ \\
\hline \multirow{2}{*}{ Ln (R\&D subsidy) } & $1.674^{* * *}$ & $1.191^{\star}$ & $0.087^{\star *}$ & & & \\
\hline & $(0.791)$ & $(0.852)$ & $(0.051)$ & & & \\
\hline Ln (R\&D subsidy) & & & & $1.113^{* *}$ & $2.581^{* *}$ & $0.051^{* *}$ \\
\hline${ }^{\star} T_{1}$ & & & & $(0.691)$ & $(1.722)$ & $(0.031)$ \\
\hline Ln (R\&D subsidy) & & & & $4.012^{* * *}$ & $3.804^{* *}$ & $0.094^{* * *}$ \\
\hline${ }^{\star} T_{2}$ & & & & $(1.571)$ & (1.995) & $(0.187)$ \\
\hline Ln ( $R \& D$ subsidy) & & & & $-0.937^{\star *}$ & $-1.118^{*}$ & $0.043^{* *}$ \\
\hline${ }^{\star} T_{3}$ & & & & $(0.511)$ & $(0.752)$ & $(0.271)$ \\
\hline \multirow{2}{*}{ Ln (Researchers) } & $0.082^{*}$ & $0.046^{*}$ & $0.041^{* * *}$ & $0.073^{* * *}$ & $0.52^{* * *}$ & $0.081^{* * *}$ \\
\hline & $(0.067)$ & $(0.032)$ & $(0.012)$ & $(0.033)$ & $(0.031)$ & $(0.042)$ \\
\hline \multirow{2}{*}{ Ln (workers) } & 0.027 & 0.021 & 0.044 & 0.021 & 0.024 & 0.046 \\
\hline & $(0.135)$ & $(0.477)$ & $(0.148)$ & $(1.085)$ & $(1.325)$ & $(0.988)$ \\
\hline \multirow{2}{*}{ Firm's age } & $0.175^{* *}$ & $0.021^{* *}$ & $0.051^{* *}$ & $0.125^{\star *}$ & $0.023^{* *}$ & $0.053^{* *}$ \\
\hline & $(0.085)$ & $(0.012)$ & $(0.032)$ & $(0.067)$ & $(0.014)$ & $(0.031)$ \\
\hline \multirow{2}{*}{$\begin{array}{c}\text { Shareholding } \\
\text { structure }\end{array}$} & 0.113 & $0.236^{* *}$ & $0.321^{\star}$ & $0.115^{\star}$ & $0.241^{\star *}$ & $0.351^{\star *}$ \\
\hline & $(0.134)$ & $(0.192)$ & $(0.261)$ & $(0.095)$ & $(0.146)$ & $(0.211)$ \\
\hline \multirow{2}{*}{ _Cons } & $1.446^{* *}$ & $0.226^{* * *}$ & $2.511^{* *}$ & $2.514^{* * *}$ & $1.446^{* * *}$ & $1.606^{* * *}$ \\
\hline & $(0.871)$ & $(0.031)$ & $(1.473)$ & $(1.098)$ & $(0.341)$ & $(0.122)$ \\
\hline$N$ & 6715 & 6715 & 6715 & 6715 & 6715 & 6715 \\
\hline Adj. $R^{2}$ & 0.056 & 0.063 & 0.071 & 0.103 & 0.116 & 0.121 \\
\hline
\end{tabular}

Note: ${ }^{* *},{ }^{* *}$, and ${ }^{*}$ indicate significance levels of $1 \%, 5 \%$, and $10 \%$, respectively.

R\&D investment of the company, with a coefficient of 1.113 . That is, on average, the proportion of $R \& D$ subsidies will increase by $1 \%$, and the private $R \& D$ expenditure of enterprises will increase by $1.113 \%$. When the proportion of government $\mathrm{R} \& \mathrm{D}$ subsidies in total $\mathrm{R} \& \mathrm{D}$ expenses is greater than $1.1 \%$ and less than $178.2 \%$, the private $\mathrm{R} \& \mathrm{D}$ expenditure of subsidized companies will increase significantly, at this time the coefficient will rise to 4.012. This shows that the R\&D subsidy effectively drives the private R\&D investment of enterprises, that is, it has a "crowding in" effect.

When the proportion of $R \& D$ subsidies in total $R \& D$ expenses is greater than $178.2 \%$, the coefficient of $R \& D$ subsidies becomes -0.937 . At this time, the government's $R \& D$ subsidies will have a negative impact on the private $R \& D$ investment of enterprises, that is, the "crowding out" effect. However, in reality, is 
it possible that the government's $R \& D$ subsidy will reach the threshold of $178.2 \%$ of the total R\&D expenses? If not, does the "crowding out" effect of R\&D subsidies instructive meaning for the pharmaceutical industry? In fact, in our sample, the highest proportion of R\&D subsidies is only $15.6 \%$, which is far below the threshold of the crowding-out effect of $178.2 \%$.

Such a high crowing out threshold is closely related to the characteristics of high-input, high-risk, and long-circle. The research and development of new drugs require a continuous and large amount of funding, and subsidy can hardly produce crowding-out effects.

As a result of column 5, the government research and development subsidy for new product sales do have both "promotion" and "damage" effects. When the proportion of R\&D subsidies from the government in the total R\&D expenditure is less than $6.5 \%$ on average, the proportion of $\mathrm{R} \& \mathrm{D}$ subsidies increases by $1 \%$ and new product sales of pharmaceutical companies increase by $2.581 \%$. When the ratio of research and development subsidies is greater than $6.5 \%$ and less than $81.9 \%$, the promotion effect of research and development subsidies is more significant, and the coefficient rises to 3.804. When the proportion of R\&D subsidies is higher than $81.9 \%$, the "damage" effect begins to appear, and the coefficient becomes -1.118 . This may be caused by excessive resources invested in $\mathrm{R} \& \mathrm{D}$ by the enterprise, resulting in insufficient resources for new product marketing and channel construction, but the $81.9 \%$ threshold actually does not exist in reality.

In column 6, the government R\&D subsidy only has a "promotion" effect on the number of patents. When the proportion of government R\&D subsidies in the total R\&D expenditure of enterprises is less than $2.7 \%$, on average, the proportion of $\mathrm{R} \& \mathrm{D}$ subsidies in total $\mathrm{R} \& \mathrm{D}$ expenditure increased by $1 \%$, and the number of patents increases by $0.051 \%$. When the proportion of R\&D subsidies in the total $R \& D$ expenditure of enterprises is greater than $2.7 \%$ and less than $198.2 \%$, the impact of $R \& D$ subsidies on the number of patents has increased significantly to 0.094 , that is, the proportion of $\mathrm{R} \& \mathrm{D}$ subsidies in total R\&D expenditure increased by $1 \%$, and the number of patents increased by $0.094 \%$. When the proportion of R\&D subsidies exceeds $198.2 \%$ of the total R\&D expenditure of enterprises, $R \& D$ subsidies still have a positive effect on the number of patents, but the coefficient drops to 0.043 .

\subsection{Robustness Test}

Considering that many scholars have pointed out that the appearance of R\&D subsidies has a time lag (Zhang, Chen, \& Yang, 2015), that is, the effects of R\&D subsidies may not work immediately. In order to solve this problem, we also collected sample data of government subsidies obtained in 2008 and 2009 from sample companies and averaged the subsidy data for the three years of 2008 , 2009 , and 2010 to reduce the possible impact of time lag on the results.

Table 5 shows the estimated thresholds for using average subsidy data. Comparing Table 2, it can be found that the threshold value has not changed much 
Table 5. Threshold value estimation results.

\begin{tabular}{cccc}
\hline Threshold type & Private R\&D investment & New product sales & Number of patents \\
\hline \multirow{2}{*}{ First threshold } & 0.017 & 0.068 & 0.039 \\
& {$[0.0161,0.0178]$} & {$[0.0646,0.0714]$} & {$[0.037,0.0409]$} \\
Second threshold & 1.231 & 0.763 & 1.061 \\
\hline
\end{tabular}

in general, but the first threshold of R\&D subsidies has increased, while the second threshold has decreased.

In Table 6, columns 1 to 3 are the results of the ordinary least squares method, and the coefficient results are similar to the benchmark results in Table 3. In general, subsidies have a significant effect on promoting private $R \& D$ investment, sales of new products and the number of patents. In addition, the number of researchers and the age of firms also have significant positive effects on the three explanatory variables.

In the threshold return of columns 4 to 6 , for the private R\&D investment of enterprises, when the subsidy ratio is less than the second threshold, $R \& D$ subsidies will stimulate enterprises to increase private $R \& D$ expenditure. When the second threshold is exceeded, the R\&D subsidy will have a "crowding out" effect, but since the second threshold is not likely to be reached in reality, the "crowding out" effect does not actually exist in reality. Regarding the number of patents, the effect of R\&D subsidies has always been a promoting effect. Between the first threshold and the second threshold, the effect of $R \& D$ subsidies is the best.

In summary, when we use the average value of $\mathrm{R} \& \mathrm{D}$ subsidies received by companies from 2008 to 2010 for robustness testing, the conclusions in the benchmark regression are still valid.

\subsection{Endogenous Discussion}

The possible endogeneity in this paper mainly comes from the reverse causality between the explanatory variable and the explained variable. Specifically, the government's R\&D subsidies will affect the pharmaceutical companies' own $R \& D$ investment, the number of patents, and the sales of new products. In turn, the R\&D investment, the number of patents, and the sales of new products will also affect the choice and amount of government subsidy decisions. This may distort the model estimation results.

For this problem, we try to construct the instrumental variables of the industry segment to alleviate it. The pharmaceutical manufacturing industry can be subdivided into 8 three-digit code sub-industries which are manufacturing of chemical raw materials, manufacturing of pharmaceutical preparations, processing of traditional Chinese medicine pieces, manufacturing of proprietary Chinese medicines, manufacturing of veterinary drugs, manufacturing of biopharmaceutical products, manufacturing of sanitary materials and medical supplies, and 
Table 6. Regression results of robustness test.

\begin{tabular}{|c|c|c|c|c|c|c|}
\hline & 1 & 2 & 3 & 4 & 5 & 6 \\
\hline Variable & $\begin{array}{c}\text { Ln (Private } \\
\mathrm{R} \& \mathrm{D} \\
\text { investment) }\end{array}$ & $\begin{array}{c}\text { Ln (New } \\
\text { product } \\
\text { sales) }\end{array}$ & $\begin{array}{l}\text { Ln (Number } \\
\text { of patents) }\end{array}$ & $\begin{array}{c}\text { Ln (Private } \\
\mathrm{R} \& \mathrm{D} \\
\text { investment) }\end{array}$ & $\begin{array}{c}\text { Ln (New } \\
\text { product } \\
\text { sales) }\end{array}$ & $\begin{array}{l}\text { Ln (Number } \\
\text { of patents) }\end{array}$ \\
\hline Method & OLS & OLS & OLS & $\begin{array}{l}\text { Threshold } \\
\text { regression }\end{array}$ & $\begin{array}{l}\text { Threshold } \\
\text { regression }\end{array}$ & $\begin{array}{l}\text { Threshold } \\
\text { regression }\end{array}$ \\
\hline \multirow{2}{*}{ Ln (R\&D subsidy) } & $1.573^{* * *}$ & $1.231^{\star *}$ & $0.0674^{\star *}$ & & & \\
\hline & $(0.127)$ & $(0.736)$ & $(0.0371)$ & & & \\
\hline Ln (R\&D subsidy) & & & & $1.413^{\star *}$ & $0.867^{\star *}$ & $0.043^{\star *}$ \\
\hline${ }^{\star} T_{1}$ & & & & $(0.872)$ & $(0.521)$ & $(0.0283)$ \\
\hline Ln (R\&D subsidy) & & & & $2.012^{* * *}$ & $1.508^{* *}$ & $0.104^{* * *}$ \\
\hline${ }^{\star} T_{2}$ & & & & $(0.984)$ & $(0.713)$ & $(0.009)$ \\
\hline Ln (R\&D subsidy) & & & & $-0.865^{\star *}$ & $-0.718^{\star}$ & $0.063^{\star *}$ \\
\hline${ }^{\star} T_{3}$ & & & & $(0.476)$ & $(0.616)$ & $(0.032)$ \\
\hline \multirow{2}{*}{ Ln (Researchers) } & $0.071^{\star}$ & $0.025^{\star}$ & $0.064^{\star * *}$ & $0.084^{* *}$ & $0.062^{\star * *}$ & $0.074^{* * *}$ \\
\hline & $(0.035)$ & $(0.018)$ & $(0.023)$ & $(0.047)$ & $(0.009)$ & $(0.026)$ \\
\hline \multirow{2}{*}{ Ln (workers) } & 0.019 & 0.076 & 0.043 & 0.013 & 0.014 & 0.032 \\
\hline & $(0.391)$ & $(0.277)$ & $(0.223)$ & $(0.199)$ & $(1.326)$ & $(0.387)$ \\
\hline \multirow{2}{*}{ Firm's age } & $0.156^{* *}$ & $0.034^{\star \star}$ & $0.065^{\star *}$ & $0.211^{* *}$ & $0.005^{\star *}$ & $0.044^{* *}$ \\
\hline & $(0.073)$ & $(0.021)$ & $(0.381)$ & $(0.196)$ & $(0.003)$ & $(0.028)$ \\
\hline \multirow{2}{*}{$\begin{array}{l}\text { Shareholding } \\
\text { structure }\end{array}$} & 0.122 & $0.245^{\star \star}$ & $0.345^{*}$ & $0.109^{*}$ & $0.209^{* *}$ & $0.453^{* *}$ \\
\hline & (1.98) & $(2.181)$ & $(1.832)$ & $(1.891)$ & $(0.123)$ & $(0.251)$ \\
\hline \multirow[t]{2}{*}{ _cons } & $1.321^{* *}$ & $0.324^{* * *}$ & $2.143^{* *}$ & $2.675^{\star * *}$ & $2.467^{\star * *}$ & $1.695^{\star * *}$ \\
\hline & $(0.712)$ & $(0.019)$ & (1.563) & $(0.489)$ & $(0.972)$ & $(0.278)$ \\
\hline$N$ & 6715 & 6715 & 6715 & 6715 & 6715 & 6715 \\
\hline adj. $R^{2}$ & 0.083 & 0.081 & 0.067 & 0.111 & 0.131 & 0.139 \\
\hline
\end{tabular}

Note: ${ }^{* * *}{ }^{* *}$, and ${ }^{*}$ indicate significance levels of $1 \%, 5 \%$, and $10 \%$, respectively.

pharmaceutical excipients and packaging materials. We construct a three-digit industry-level government $R \& D$ subsidy growth rate variable to reflect the intensity of government R\&D support policy and its changes.

The appropriateness of constructing instrumental variables in this way is that the government's R\&D subsidy policy aims to support some specific industries to improve their independent innovation capabilities through incentives, tax reductions, and grants. The change in the incentives or support strengths of subsidy policies must be reflected by information on the total amount of growth rate of $\mathrm{R} \& \mathrm{D}$ subsidies. Therefore, the growth rate of government $\mathrm{R} \& \mathrm{D}$ subsidies at the industry level directly reflects information at the policy level.

In this case, the growth rate of government R\&D subsidies at the industry level is not directly related to private $R \& D$ investment, patents, and new product 
sales at the individual enterprise level, but directly related to government $R \& D$ subsidies received by individual enterprises at the industry level. It meets the design requirements of tool variables.

Table 7 shows the results of the instrumental variable regression. In terms of private $R \& D$ investment, when the $R \& D$ subsidy is less than the first threshold, the promotion effect of $\mathrm{R} \& \mathrm{D}$ subsidy is smaller than the previous result. The effect is most pronounced when the R\&D subsidy is between the first and second thresholds, and it is negative when it is greater than the second threshold. However, as the situation above the second threshold does not exist in reality, the squeeze-out effect of R\&D subsidies does not actually work.

In terms of sales of new products, when the $R \& D$ subsidy is less than the first

Table 7. Instrumental variable regression results.

\begin{tabular}{|c|c|c|c|c|c|c|}
\hline & 1 & 2 & 3 & 4 & 5 & 6 \\
\hline Variables & $\begin{array}{c}\text { Ln (Private } \\
\text { R\&D } \\
\text { investment) }\end{array}$ & $\begin{array}{l}\text { Ln }(\mathrm{New} \\
\text { product } \\
\text { sales) }\end{array}$ & $\begin{array}{l}\text { Ln (Number } \\
\text { of patents) }\end{array}$ & $\begin{array}{c}\text { Ln (Private } \\
\text { R\&D } \\
\text { investment) }\end{array}$ & $\begin{array}{l}\text { Ln (New } \\
\text { product } \\
\text { sales) }\end{array}$ & $\begin{array}{c}\text { Ln (Number } \\
\text { of patents) }\end{array}$ \\
\hline Method & $\begin{array}{l}\text { Threshold } \\
\text { regression }\end{array}$ & $\begin{array}{l}\text { Threshold } \\
\text { regression }\end{array}$ & $\begin{array}{l}\text { Threshold } \\
\text { regression }\end{array}$ & IV & IV & IV \\
\hline \multirow{2}{*}{ Ln ( $R \& D$ subsidy) } & $1.113^{* *}$ & $2.581^{* *}$ & $0.051^{\star *}$ & $0.464^{* *}$ & $0.348^{\star *}$ & $0.072^{\star *}$ \\
\hline & $(0.696)$ & $(1.349)$ & $(0.027)$ & $(0.242)$ & $(0.169)$ & $(0.039)$ \\
\hline Ln (R\&D subsidy) & $4.012^{\star * *}$ & $3.804^{* *}$ & $0.094^{* * *}$ & $2.435^{\star * *}$ & $1.508^{\star *}$ & $0.104^{\star * *}$ \\
\hline${ }^{*} T_{1}$ & $(2.001)$ & $(2.189)$ & $(0.042)$ & $(0.877)$ & $(0.981)$ & $(0.007)$ \\
\hline Ln (R\&D subsidy) & $-0.937^{\star *}$ & $-1.118^{\star}$ & $0.043^{* *}$ & $-0.037^{\star *}$ & $-0.629^{*}$ & $0.033^{* *}$ \\
\hline${ }^{\star} T_{2}$ & $(0.467)$ & $(0.865)$ & $(0.027)$ & $(0.017)$ & $(0.591)$ & $(0.018)$ \\
\hline Ln (R\&D subsidy) & $0.073^{* * *}$ & $0.52^{\star * *}$ & $0.081^{\star * *}$ & $0.068^{* * *}$ & $0.016^{* * *}$ & $0.092^{* * *}$ \\
\hline${ }^{\star} T_{3}$ & $(0.021)$ & $(0.115)$ & $(0.012)$ & $(0.008)$ & $(0.007)$ & $(0.025)$ \\
\hline \multirow{2}{*}{ Ln (researchers) } & 0.021 & 0.024 & 0.046 & 0.011 & 0.023 & 0.009 \\
\hline & $(1.088)$ & $(1.329)$ & $(0.988)$ & $(0.895)$ & $(1.126)$ & $(1.116)$ \\
\hline \multirow{2}{*}{ Ln (workers) } & $0.125^{\star *}$ & $0.023^{* *}$ & $0.053^{* *}$ & $0.025^{\star *}$ & $0.025^{\star *}$ & $0.301^{\star *}$ \\
\hline & $(0.778)$ & $(0.015)$ & $(0.035)$ & $(0.019)$ & $(0.018)$ & $(0.158)$ \\
\hline \multirow{2}{*}{ Firm's age } & $0.115^{\star}$ & $0.241^{\star *}$ & $0.351^{\star *}$ & $0.132^{*}$ & $0.119^{* *}$ & $0.129^{* *}$ \\
\hline & $(0.911)$ & $(0.132)$ & $(0.171)$ & $(0.098)$ & $(0.073)$ & $(0.071)$ \\
\hline \multirow{2}{*}{$\begin{array}{c}\text { Shareholding } \\
\text { structure }\end{array}$} & $2.514^{\star * *}$ & $1.446^{* * *}$ & $1.606^{\star * *}$ & $2.509^{* * *}$ & $1.532^{\star * *}$ & $1.781^{\star * *}$ \\
\hline & $(0.098)$ & $(0.651)$ & $(0.554)$ & $(1.007)$ & $(0.632)$ & $(0.119)$ \\
\hline \multirow[b]{2}{*}{ _cons } & 0.924 & -0.424 & -0.442 & 0.558 & $2.118^{\star *}$ & $1.610^{* * *}$ \\
\hline & $(1.310)$ & $(0.626)$ & $(2.095)$ & $(1.415)$ & $(0.933)$ & $(0.389)$ \\
\hline First stage $F$ & & & & 11.23 & 11.51 & 11.84 \\
\hline$N$ & 6715 & 6715 & 6715 & 6715 & 6715 & 6715 \\
\hline $\operatorname{adj} . R^{2}$ & 0.111 & 0.131 & 0.139 & 0.122 & 0.139 & 0.198 \\
\hline
\end{tabular}

Note: ${ }^{* *},{ }^{* *}$, and ${ }^{*}$ indicate significance levels of $1 \%, 5 \%$, and $10 \%$, respectively. 
threshold, the promotion effect of R\&D subsidy is narrowed compared to the previous results. The results of other states have also changed little compared with the previous ones. The results for the number of patents are similar to those for OLS regression.

Therefore, when we construct the three-digit industry level government R\&D subsidy growth rate as an instrumental variable for regression, the results are consistent with the benchmark results, which confirms the robustness of our benchmark results.

\section{Conclusion}

This article uses microdata from pharmaceutical companies to examine the impact of government $R \& D$ subsidies on private $R \& D$ investment, the number of patents, and sales of new products.

First, the benchmark results suggest that when the government R\&D subsidy accounts for less than $1.1 \%$ of the company's total R\&D expenditure, the government $R \& D$ subsidy will start to promote the private $R \& D$ investment of the company, with a coefficient of 1.113 . When the proportion of government $\mathrm{R} \& \mathrm{D}$ subsidies in total $R \& D$ expenses is greater than $1.1 \%$ and less than $178.2 \%$, the private $R \& D$ expenditure of subsidized enterprises will increase significantly, and the coefficient will rise to 4.012 . R\&D subsidies effectively drive private $\mathrm{R} \& \mathrm{D}$ investment of enterprises, that is, they have a "crowding in" effect.

However, when the proportion of $R \& D$ subsidies in total $R \& D$ expenses is greater than $178.2 \%$, the coefficient of R\&D subsidies becomes -0.937 . At this time, the government's R\&D subsidies will have a negative impact on the private R\&D investment of enterprises, that is, the "crowding out" effect, But this squeeze threshold will not be reached in practice. Our sample data also supports this judgment. In our sample, the highest proportion of R\&D subsidies reached $15.6 \%$, which is far below the threshold of the crowding-out effect of $178.2 \%$.

The impact of $R \& D$ subsidies on new product sales is similar to the previous scenario, but for the number of patents, no matter what threshold the R\&D subsidy is in, the impact of $R \& D$ subsidies on the number of patents is positive.

In addition, considering that the effect of $\mathrm{R} \& \mathrm{D}$ subsidies will be time-lagging, we used the average value of $R \& D$ subsidies of sample companies from 2008 to 2010 to perform robustness tests, and the conclusion is still valid. Finally, we construct a three-digit industry-level government $\mathrm{R} \& \mathrm{D}$ subsidy growth rate variable to address the endogenous inverse causality between the explanatory variables and the explanatory variables that may appear.

The contribution of this study is to prove that $R \& D$ subsidies have no squeeze effect on private $R \& D$ investment in the pharmaceutical industry. In addition, it is emphasized that differences in R\&D activities in different industries should be included in $R \& D$ subsidy research.

\section{Conflicts of Interest}

The authors declare no conflicts of interest regarding the publication of this paper. 


\section{References}

Chen, L. (2018). Re-Exploring the Usage of China's Industrial Enterprise Database. Economic Review, 6, 140-153.

Gorg, H., \& Strobl, E. (2007). The Effect of R\&D Subsidies on Private R\&D. Economica, 294, 215-234. https://doi.org/10.1111/j.1468-0335.2006.00547.x

Hansen, B. E. (1999). Threshold Effects in Non-Dynamic Panels: Estimation, Testing, and Inference. Journal of Econometrics, 93, 345-368. https://doi.org/10.1016/S0304-4076(99)00025-1

Klette, T. J., \& Moen, J. (2011). R\&D Investment Responses to R\&D Subsidies: A Theoretical Analysis and a Micro Econometric Study. NHH Dept. of Finance \& Management Science Discussion Paper. https://doi.org/10.2139/ssrn.1940407

Li, R., \& Ba, J. (2013). The Effect of Government R\&D Subsidies on Enterprise Technology Innovation: An Empirical Research Based on Threshold Regression. Economic Issues in China, 3, 11-23.

Lach, S. (2002). Do R\&D Subsidies Stimulate or Displace Private R\&D? Evidence from Israel. Journal of Industrial Economics, 4, 369-390. https://doi.org/10.1111/1467-6451.00182

Wallsten, S. J. (2000). The Effects of Government-Industry R\&D Programs on Private R\&D: The Case of the Small Business Innovation Research Program. The Rand Journal of Economics, 1, 82-100. https://doi.org/10.2307/2601030

Zhang, J., Chen, Z., \& Yang, L. (2015). On Evaluating China's Innovation Subsidy Policy: Theory and Evidence. Economic Research Journal, 10, 4-17.

Zhao, N., \& Sun, L. (2018). Research on R\&D Capability of New Drugs in Chinese Pharmaceutical Industry. Chinese Journal of Pharmaceuticals, 9, 1321-1326.

Zhu, P., \& Xu, W. (2003). On The Impact of Government's S\&T Incentive Policy on the R\&D Input and Its Patent Output of Large and Medium-Sized Industrial Enterprises in Shanghai. Economic Research Journal, 6, 45-53. 